\title{
Growth and mortality of Cichla spp. (Perciformes, Cichlidae) introduced in Volta Grande Reservoir (Grande River) and in a small artificial lake in Southeastern Brazil
}

\author{
Gomiero, LM.*, Carmassi, AL., Rondineli, GR., Villares Junior, GA. and Braga, FMS. \\ Departamento de Zoologia, Instituto de Biociências, Universidade Estadual Paulista - UNESP, \\ Av. 24-A, 1515, CP 199, CEP 13506-900, Rio Claro, SP, Brazil \\ *e-mail: leanmg@rc.unesp.br \\ Received September 9, 2009 - Accepted December 28, 2009 - Distributed November 30, 2010
}

(With 5 figures)

\begin{abstract}
The growth and mortality parameters were estimated through the analysis of length frequency distribution for species of Cichla spp. introduced into a lake in Leme (SP), and in Volta Grande reservoir (SP-MG). In Leme, Cichla kelberi presented larger frequency in the inferior classes of lengths, larger instantaneous rate of natural mortality, and smaller number of cohorts than $C$. kelberi and $C$. piquiti in Volta Grande. The values of growth performance obtained for the species were similar, corroborating the validity of the estimated growth and mortality parameters. The increase of the growth rate in small and less diverse environments occurs due to predation. The genus Cichla adapts well in locations in which it is introduced, however this adaptation shows itself to be strongly adjusted to each particular location, determining great plasticity and establishment capacity.
\end{abstract}

Keywords: introduction of species, growth, mortality, Cichla kelberi, Cichla piquiti.

\section{Crescimento e mortalidade de Cichla spp. (Perciformes, Cichlidae) introduzido no reservatório de Volta Grande (Rio Grande) e em um pequeno lago artificial no Sudeste do Brasil}

\begin{abstract}
Resumo
Os parâmetros de crescimento e mortalidade foram estimados indiretamente pelas distribuições das frequências de comprimento para espécies de Cichla spp. introduzidas em um lago em Leme (SP) e no reservatório de Volta Grande (SP-MG). Em Leme, Cichla kelberi apresentou maior frequência nas classes de comprimentos inferiores, maior taxa instantânea de mortalidade natural e menor número de coortes do que $C$. kelberi e C. piquiti em Volta Grande. Os valores de performance de crescimento obtidos para as espécies foram próximos, corroborando a validade dos parâmetros estimados de crescimento e de mortalidade. A pressão em crescer rapidamente, devido à predação, aumenta quanto menor e menos diverso for o ambiente. O gênero Cichla adapta-se bem nos locais em que é introduzido, entretanto essa adaptação mostra-se fortemente ajustada a cada ambiente em particular, determinando com isso grande plasticidade e capacidade de estabelecimento.
\end{abstract}

Palavras-chave: introdução de espécies, crescimento, mortalidade, Cichla kelberi, Cichla piquiti.

\section{Introduction}

The species of Cichla are being introduced, deliberately or not, into several lentic environments of southeastern Brazil. Besides this region, they were introduced into other locations, such as Florida, Hawaii, Panama and Puerto Rico (Hoeinghaus et al., 2003). The introductions of this genus are very dangerous and it is presumed to be the second largest cause of extinctions, only surpassed by the degradation and loss of habitats (Simberloff, 2003).

The reservoirs of hydroelectric plants are preferential environments for this practice, aggravating the depletion of native species due to the transfer of pathogens, predation, competition and the possible cascade effects across the food chain (Zaret and Paine, 1973; Agostinho and Julio Jr., 1996; Elvira and Almodóvar, 2001). Moreover, the peacock bass attracts some fishermen, so that occupies riverine communities that previously depended on the exploitation of native species (Gomiero and Braga, 2004b). Furthermore, the control of other fish species and the quality of their meat are the attributes considered for the introduction of this voracious predator (Zaret, 1980).

The peacock bass are native species in the Amazon basin. The peacock bass proliferates easily, due to parental 
care (Gomiero and Braga, 2004c), and the lack of predators allows it to invade and adapt very well to new environments. Soon after the introductions, exponential growth in numbers is common, causing intraspecific competition for space and food with consequent loss of biomass (Williams et al., 1998; Bedarf et al., 2001).

According to Pauly (1998), fish size determines the type of interaction with other organisms and demography characteristics. This size is determined partially by genetics and environmental conditions (Lowe-McConnell, 1999).

In tropical areas, increase in length is faster than in temperate systems. It can be explained by the high temperatures that accelerate the metabolism and maturation, which leads to a shorter lifetime and higher values of mortality (Machado-Allison, 1990). It is more difficult to determine ages and growth rates in fish under tropical conditions, where the growth rings in scales, bones and otoliths are not as apparent as the winter rings in the structures of fish in temperate zones (Lizama and Vazzoler, 1993; LoweMcConnell, 1999). Therefore, the use of indirect methods for estimating growth parameters has been employed in several studies in the tropical region (Ruffino and Isaac, 1995; Lizama and Ambrósio, 2003; Mateus and Petrere Jr., 2004; Gomiero et al., 2007; Carmassi et al., 2008). These methods use data of length frequency distribution that contains information about the average length in each age group, and the position of modas associated with cohorts (Basson et al., 1988).

The parameters of growth and mortality in populations are greatly influenced by interactions with other species through competition for food and/or space, and by predation (Sparre and Venema, 1992). Furthermore, the populations of different locations are under the influence of different ecosystem productivity, with different distributions of length, growth rates and age structures (Machado-Allison, 1990). Therefore, the estimated age structure, growth rate and longevity are essential to manage these stocks that are already being exploited in areas with little ecological knowledge (Jepsen et al., 1999).

Due to the dimension and maturity differences of the two environments, greater mortality and growth rates are expected, in that the peacock bass population has great density and smaller biotic conditions for development. The aim of this study was to estimate and compare the growth and mortality parameters of the yellow peacock bass, Cichla kelberi Kullander and Ferreira, 2006 introduced into an artificial lake in Leme (SP) and into the reservoir of UHE Volta Grande (SP-MG ) and the blue peacock bass, Cichla piquiti Kullander and Ferreira, 2006 introduced into the same reservoir.

\section{Material and Methods}

The Volta Grande Reservoir, located in a tropical area $\left(48^{\circ} 25^{\prime}-47^{\circ} 35^{\prime} \mathrm{W}\right.$ and $\left.19^{\circ} 57^{\prime}-20^{\circ} 10^{\prime} \mathrm{S}\right)$, resulted from the damming of the Grande River approximately 30 years ago, to produce electric energy. The result was a flooded area of $221.7 \mathrm{~km}^{2}$ with a volume of $2,268 \mathrm{~km}^{3}$. The climate is typically tropical with an average annual temperature of $22{ }^{\circ} \mathrm{C}$ and an average annual rainfall of 1,635 $\mathrm{mm}$. The two seasonal periods are: warm and rainy from October to April, and cool and dry from May to September (Braga and Gomiero, 1997). The reservoir has a great abundance of the peacock bass Cichla piquiti and Cichla kelberi. We sampled the fish monthly from September 1997 to August 1998, using fishing poles and artificial bait (baitcasting). This type of fishing is effective for the capturing of peacock bass in a wide variety of environments (Taphorn and Barbarino-Duque, 1996; Braga and Gomiero, 1997; Jepsen et al., 1999; Winemiller, 2001; Gomiero and Braga, 2003a).

The lake in Leme (SP) is located in a tropical area $\left(47^{\circ}\right.$ $\left.18^{\prime} \mathrm{W}, 22^{\circ} 13^{\prime} \mathrm{S}\right)$. The lake was built more than 50 years ago and has about $2.5 \mathrm{~km}$ of shoreline, a length of $860 \mathrm{~m}$ between the two most distant points, and $83 \mathrm{~m}$ between the closest two points, with a flooded area of about $0.36 \mathrm{~km}^{2}$. The climate is typical of tropical regions, with an average annual temperature of $21^{\circ} \mathrm{C}$ and an average annual rainfall of $1,400 \mathrm{~mm}$. There are two typical seasonal periods: the hot and rainy period, which begins in October and lasts until April, and a colder one, the dry season, from May to September. Twenty years ago, Cichla kelberi (from the Tocantins basin) was introduced. This introduction was done aiming at controlling populations of another exotic fish species, the tilapia, Oreochromis niloticus Linnaeus, 1757 and Tilapia rendalli Boulenger, 1912. A total of 12 samples were made monthly in April 2006 to March 2007. The collections were carried out similarly as in the Volta Grande Reservoir.

Total length $(\mathrm{cm})$, total mass (grams), and sex were obtained for each individual (Braga, 1990).

The growth parameters were estimated by ELEFAN I (Electronic Lengths-Frequency Analysis), and for its application we used the program FISAT (FAO-ICLARM Stock Assessment Tools) (Pauly and David, 1981; Gayanilo et al., 1996; Gayanilo and Pauly, 1997). This program is based on modal shift from temporal sequences of samples of length (Castro et al., 2002) using the seasonal version of the growth curve of von Bertalanffy (Sparre and Venema, 1992), whose model is (Equation 1):

$$
\begin{aligned}
& \mathrm{L}_{\mathrm{t}}=\mathrm{L} \infty \times\left[1-\exp \left\{\left(-\mathrm{K} \times\left(\mathrm{t}-\mathrm{t}_{0}\right)-(\mathrm{CK} / 2 \mathrm{p}) \times\right.\right.\right. \\
& \left.\left.\times \operatorname{seno}\left(2 \mathrm{p} \times\left(\mathrm{t}-\mathrm{t}_{\mathrm{s}}\right)\right)\right\}\right]
\end{aligned}
$$

where: Lt is the length at age $t ; \pi$ is equivalent to 3.14159 , and $t_{s}$ is the season of greatest growth rate, which can be calculated through the expression $t_{s}=0.5+\mathrm{Wp}$. Thus, the model used considers not only the parameters $\mathrm{L} \infty$ (asymptotic length) and $\mathrm{K}$ (growth rate), but also two other parameters: WP (winter point) and C (amplitude of oscillation). The value of $\mathrm{C}$ is related to the difference in average surface temperatures of the water for winter and summer, $\mathrm{Wp}$ is the season when growth is slower, with a ratio of number of days until the month of slower growth of the species with the number of days of the year (Pauly and Gaschutz, 1979). 
The asymptotic length $(\mathrm{L} \infty)$ was estimated from the largest individual captured $\left(\mathrm{L}_{\max }\right)$, where (Pauly, 1983) (Equation 2):

$\mathrm{L} \infty=\mathrm{L}_{\max } / 0,95$

The index of growth performance $(\varphi$ ') was used to compare growth parameters of Cichla kelberi species in the lake in Leme and in the Volta Grande Reservoir, and Cichla piquiti in Volta Grande Reservoir, according to the equation of Pauly and Munro (1984) apud Castro et al. (2002) (Equation 3):

$\varphi^{\prime}=\log _{10} \mathrm{k}+2 \times \log _{10} \mathrm{~L} \infty$

As it is unlikely that a fish species grows according to this equation from the moment it is born until senility, the curve often cuts the $\mathrm{x}$-axis, related to age, usually at a point less than zero (King, 1996). To calculate the parameter $\mathrm{t}_{0}$, theoretical age at length zero, of the equation of von Bertalanffy growth, we used the empirical formula of Pauly (1979) (Equation 4):

$\log _{10}($-to $)=-0,3922-0,2752 \times$

$\times \log _{10} \mathrm{~L} \infty-1,038 \times \log _{10} \mathrm{k}$

Longevity, defined as the lifetime of the individual, was estimated based on the formulas proposed by Pauly (1983) (Equation 5):

$\mathrm{t}_{\text {max }}=3 / \mathrm{k}$

The instantaneous rate of natural mortality (M) was estimated using the following parameters: growth rate $(\mathrm{K})$, asymptotic length $(\mathrm{L} \infty)$ and average water temperature in degrees Celsius $\left(\mathrm{T}^{\circ}\right)$ over the period, according to the empirical formula proposed by Pauly (1980), where (Equation 6):

$\log _{10} \mathrm{M}=-0,0066-0,279 \times$

$\times \log _{10} \mathrm{~L} \infty+\log _{10} \mathrm{k}+0,4634 \times \log _{10} \mathrm{~T}^{\circ}$

The estimate of the instantaneous rate of total mortality (Z) was performed by:

$\mathrm{Z}=\mathrm{M}+\mathrm{F}$

where: $\mathrm{F}$ is the fishing mortality, which in both locations was considered equal to zero because there isn't exploratory fishing of the species, then (Equation 7):

$\mathrm{Z}=\mathrm{M}$

The survival rate (S) was estimated according to the formula of Ricker (1975) (Equation 8):

$\mathrm{S}=\mathrm{e}^{-\mathrm{Z}}$

\section{Results}

Total length data of 144 specimens of $C$. kelberi (11.2 to $54.8 \mathrm{~cm})$ and 319 specimens of $C$. piquiti $(10.5$ to $54.3 \mathrm{~cm})$ in the Volta Grande Reservoir were used, and in the lake in Leme 544 specimens of $C$. kelberi ( 5.2 to $42.2 \mathrm{~cm}$ ). The three distributions in length classes for the whole period showed that the more frequent class for $C$. kelberi in Leme was 14 to $18 \mathrm{~cm}$, and in Volta Grande it was 38 to $42 \mathrm{~cm}$, whereas for $C$. piquiti, the classes with 30 to $42 \mathrm{~cm}$ were the most frequent (Figure 1).

The distributions of the length classes of $C$. kelberi (Leme, SP) varied seasonally. The distribution in the spring season presented a small moda in the class 18 to $26 \mathrm{~cm}$; in the summer, a great moda appeared in the class of 14 to $18 \mathrm{~cm}$; in the autumn, the moda occured in the 18 to $22 \mathrm{~cm}$ class, and the moda in the winter emerged in small classes of 18 to $26 \mathrm{~cm}$. The smaller specimens appeared mainly in the summer and in the autumn (Figure 2).

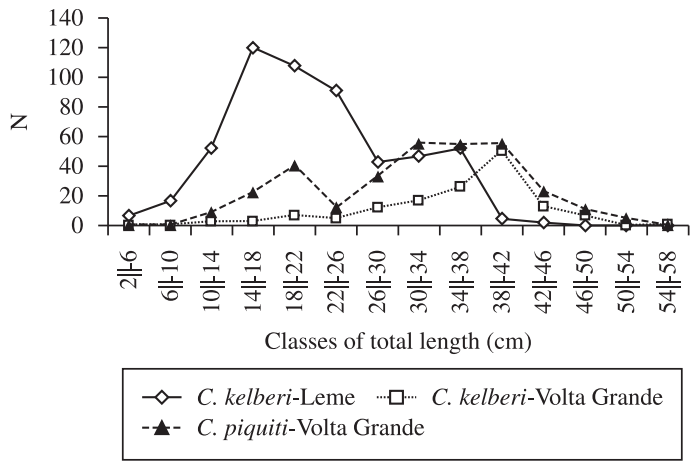

Figure 1. Numeric distribution in the total length classes of Cichla kelberi (Leme, SP), Cichla kelberi and Cichla piquiti (Volta Grande Reservoir, SP-MG).
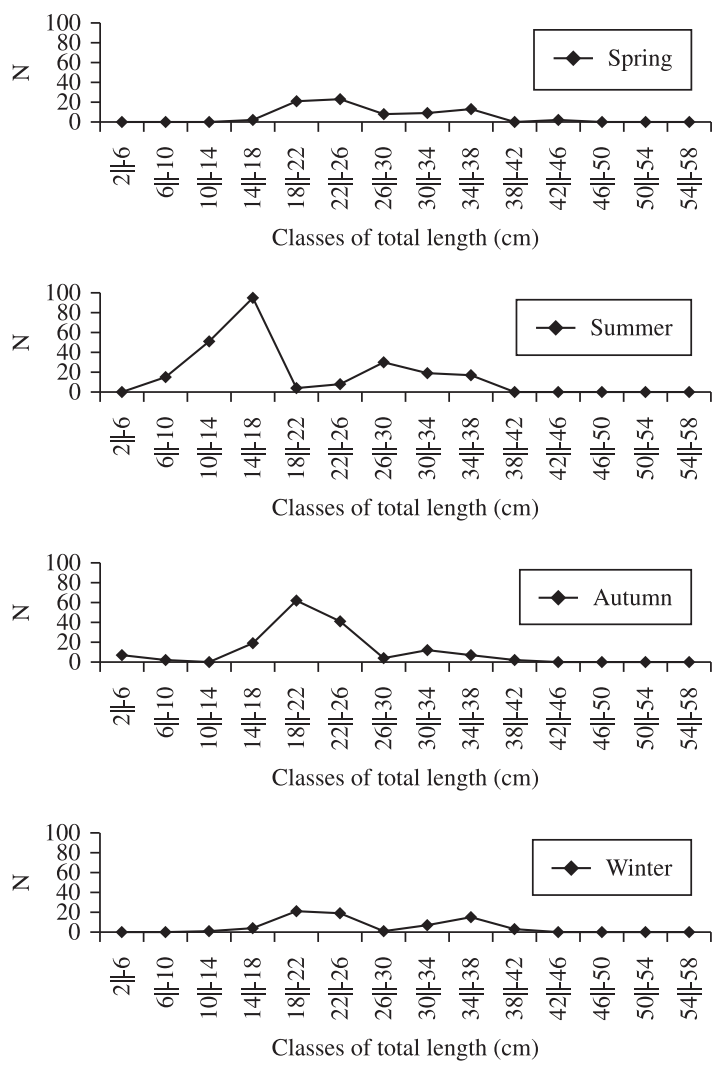

Figure 2. Numeric distribution in the total length classes of Cichla kelberi (Leme, SP) for each season. 
The length class distributions of C. kelberi (Volta Grande Reservoir, SP-MG) by season showed that in the spring there was a moda in classes 34 to $42 \mathrm{~cm}$, in the summer there was a small moda in class 26 to $30 \mathrm{~cm}$, and another in class 38 to $42 \mathrm{~cm}$; a great moda in autumm occured in class 38 to $42 \mathrm{~cm}$ and, in winter there was a moda in class 38 to $42 \mathrm{~cm}$. Specimens with smaller total length occurred in the autumm in classes from 6 to $22 \mathrm{~cm}$ (Figure 3).

The distributions of length classes of $C$. piquiti (Volta Grande Reservoir, SP-MG) showed that in spring there was a moda in classes 38 to $42 \mathrm{~cm}$, in the summer a moda appeared in class 18 to $22 \mathrm{~cm}$, and in classes 26 to $38 \mathrm{~cm}$; in autumn, the large moda occured in classes 30 to $42 \mathrm{~cm}$ and in the winter the modas appeared in classes 14 to $22 \mathrm{~cm}, 30$ to $34 \mathrm{~cm}$ and 38 to $42 \mathrm{~cm}$. The smaller specimens occurred mainly in the autumm classes from 6 to $22 \mathrm{~cm}$ (Figure 4 ).

Four to 5 cohorts were found in C. kelberi (Leme, SP), 9 to 10 for C. kelberi and 7 to 8 for C. piquiti (Volta Grande Reservoir, SP-MG). In Leme-SP the cohorts were formed in the autumn, and in the Volta Grande Reservoir, in summer (Figure 5).
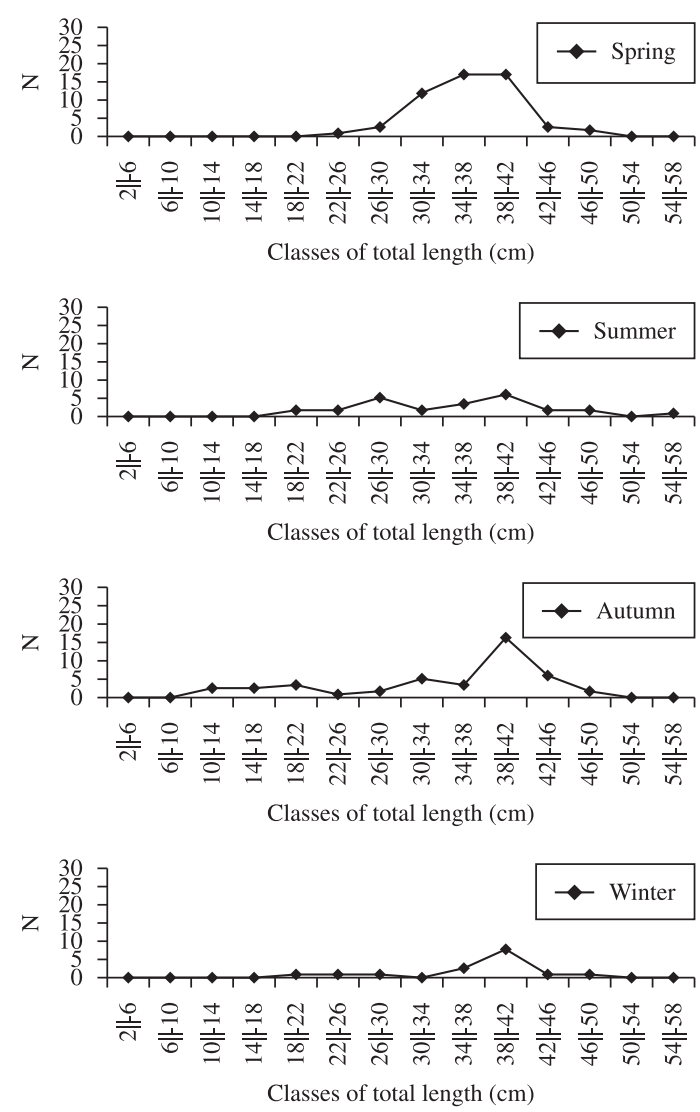

Figure 3. Numeric distribution in the total length classes of Cichla kelberi (Volta Grande Reservoir, SP-MG) for each season.
The seasonal oscillation amplitude (C) was 0.6 in Volta Grande and 0.5 in Leme, referring to a difference in the average surface temperatures of the water in the summer and in the winter that the fish were exposed to $6{ }^{\circ} \mathrm{C}$ and $5{ }^{\circ} \mathrm{C}$, respectively. The winter point (Wp) was 0.58 in Volta Grande and 0.5 in Leme, which equates to June/July. These values represent the time of year when the growth is slower. The values of the index of growth performance between $C$. piquiti and $C$. kelberi in Volta Grande and $C$. kelberi in Leme were very similar, which demonstrates that all samples that produced the growth curves were accepted as representative. The instantaneous rates of total mortality $(\mathrm{Z})$ for the three species were the same as the instantaneous rate of natural mortality (M) due to non-exploitation of its stocks in the collection areas (Pauly, 1998). The natural mortality was very high for $C$. kelberi in Leme Lake and was relatively lower for C. kelberi and $C$. piquiti in Volta Grande Reservoir. The longevity of C. kelberi in Leme was much lower than the life spans of C. kelberi and C. piquiti in Volta Grande Reservoir.

The growth parameters are presented in Table 1, mortality and the best combinations arranged by ELEFAN I, in the best settings or higher values of Rn (a goodness of fit
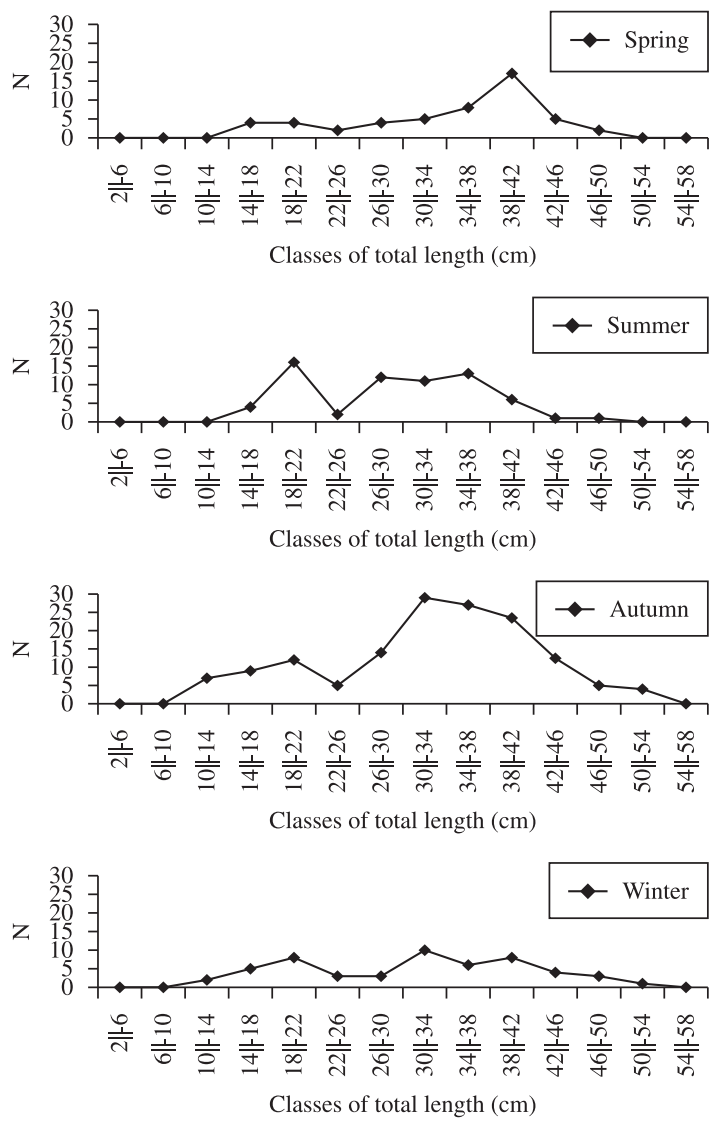

Figure 4. Numeric distribution in the total length classes of Cichla piquiti (Volta Grande Reservoir, SP-MG) for each season. 
Growth and mortality of Cichla spp.

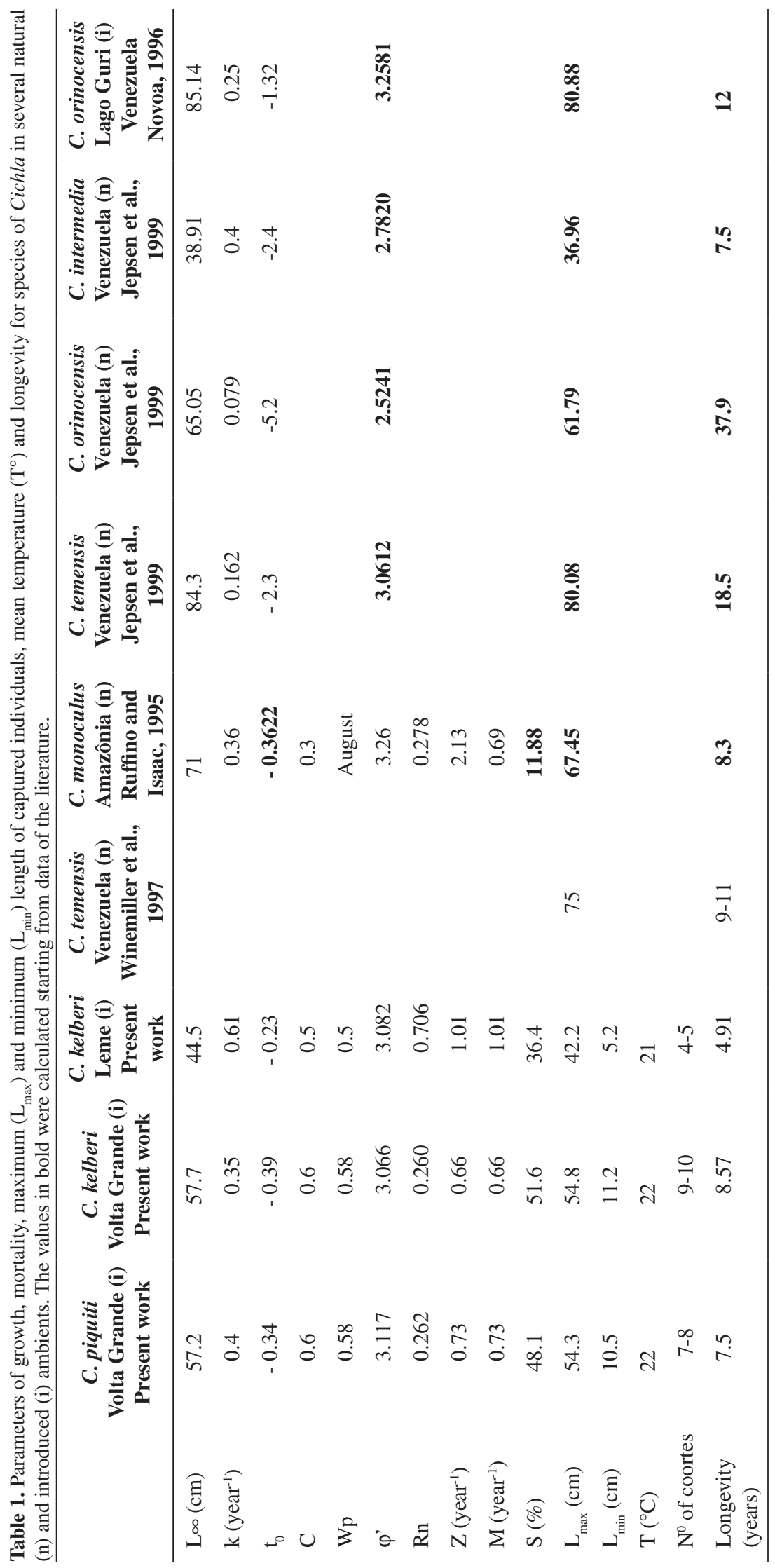


(a)

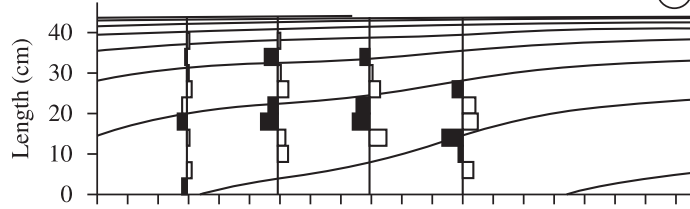

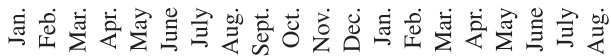
2006

2007

(b)

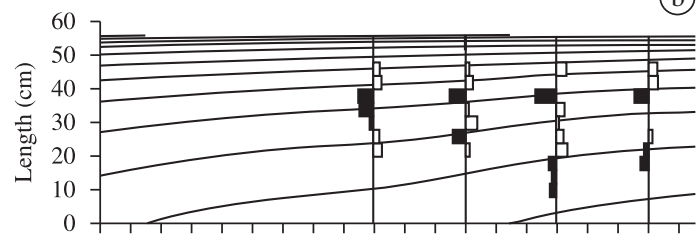

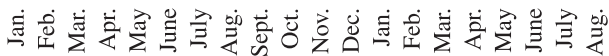
1997

1998

(c)

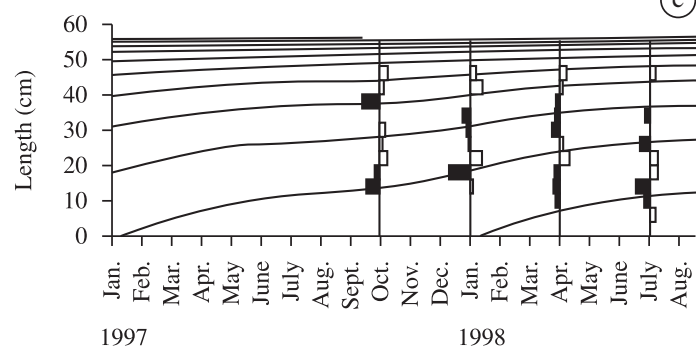

Figure 5. Growth curves of a) Cichla kelberi (Leme, SP), b) Cichla kelberi e c) Cichla piquiti (Volta Grande Reservoir, SP-MG) restructured for frequency of total length, made calculations through the system ELEFAN I (package computational FISAT).

index) for Cichla kelberi (Leme, SP), and Cichla kelberi and Cichla piquiti (Volta Grande Reservoir, SP-MG), as well as the parameters obtained in the literature of species introduced or peacock bass in natural environments.

\section{Discussion}

The yellow peacock bass, Cichla kelberi in Leme (SP) showed higher frequency in the smallest length classes when compared to C. kelberi and C. piquiti in Volta Grande Reservoir. Length distributions may vary depending on the time of introduction and the characteristics of the ecosystem (Gomiero and Braga, 2003b). To avoid the overlap in resource use, the species shows differences in body size; and, in some communities, selective predation by size can be a primary organising force (Werner and Gilliam, 1984). The disparity in length structures and the densities of the peacock bass in different places and species may be justified by the pressures of fishing, the maturation of the environments and the ecological differences (Winemiller et al.,
1997; Winemiller, 2001). In the collections sites, there is no sport practice or commercial fishing. The samples in the Reservoir were made at the dam, a forbidden place for any type of fishing except for scientific purposes, and at the lake, fishing does not occur because it is private property. Thus, the time difference from maturation of the environments and their ecological differences must be responsible for the distinct structures in length. The different sizes of the Reservoir and of the lake cannot be disregarded, with greater stability and amount of resources in the largest (reservoir) and a large density population of peacock bass with few resources in the smallest (lake) (Gomiero and Braga, 2004b; Gomiero et al., 2008).

The cohorts were formed in the summer and autumn, shortly after the peak breeding season. Reproduction at the lake in Leme (SP) and at the Volta Grande Reservoir (SP-MG) occurred in the spring and in the summer, with a greater number of young in the summer-autumn (Gomiero and Braga, 2004c; Gomiero et al., 2009), as for Cichla ocellaris (Bloch and Schneider, 1801) in Guri Reservoir (Venezuela), which presented the recruitment period in the summer and autumn when there was a predominance of classes with less total length (Jepsen et al., 1999). Espinola (2005) found that Cichla monoculus Spix and Agassiz, 1831 (= C. kelberi) had a greater frequency of juveniles in the rainy seasons, with several reproductive strategies and tactics depending on the sites, showing a high degree of phenotypic plasticity, allowing it to adapt to highly variable environments. Seasonal reproduction occurs both for the peacock bass in natural environments and for those in the environments of introductions (Zaret, 1980; Ruffino and Isaac, 1995; Jepsen et al., 1999; Resende et al., 2008; Souza et al., 2008).

The fecundity rate is changed mainly in response to food supply, which means that fecundity is an answer to the adjustments related to fluctuations in environmental conditions (Gomiero and Braga, 2004c). Fecundity is related to mortality, the species with larger fecundities support higher rates of mortality (Braga, 1999). The mortality rate of $C$. kelberi at the lake in Leme was higher than for the species in the Volta Grande Reservoir. However, the average values of fecundity were close, being 12,129 \pm 960 mature oocytes for $C$. kelberi in Leme, 17,987 \pm 2,522 oocytes for $C$. kelberi and 13,769 $\pm 3,401$ oocytes for $C$. piquiti at Volta Grande. The energy investment in reproduction and protection of offspring is related to annual spawning to most individuals (Jepsen et al., 1999), which may occur several times a year in some situations where, for example, offspring are preyed (high mortality) during the parental care due to overcrowding found in Leme (Gomiero et al., 2009).

Other factors influencing the increased rate of mortality are high growth rate, lack of resources and early sexual maturation, in which mature individuals reproduce in small sizes (dwarfism) and, depending on the conditions, have smaller oocytes, which is a form of miniaturisation (Agostinho and Julio Jr., 1996; Lowe-McConnell, 1999). In the overpopulated small lake in Leme, $C$. kelberi 
presented mature oocytes of 2,203.2 micrometres, a smaller size than presented by $C$. kelberi and C. piquiti in Volta Grande Reservoir. The diameter of oocytes is correlated with the amount of yolk, which in turn influences the development time of larvae (Nikolskii, 1963, 1969; Wootton, 1992). Braga and Gennari Filho (1991) found for Moenkhausia intermedia Eigenmann, 1908, different periods of spawning in Barra Bonita (Piaracicaba river), lots of oocytes with different diameters as a result of the conditions that the larvae found for development. In the lake in Leme, where cannibalism was common (Naous, 2008) and the mortality rate was higher, the larvae needs to have faster development to minimise predation, so it does not use for long the reserves of the yolk. Moreover, in Leme, the $\mathrm{L}_{50}$ (length at which $50 \%$ of the population of $C$. kelberi showed gonads in maturation or mature) was relatively lower than those found in C. kelberi and C. piquiti at Volta Grande (Gomiero and Braga, 2004c; Gomiero et al., 2009), so the peacock bass, in Leme, shows a certain degree of miniaturisation. Cichla ocellaris, Cichla temensis (Humboldt, 1821), Cichla orinocensis (Humboldt, 1821) and Cichla intermedia in Venezuela (native environment) (Machado-Allison, 1971) were ripe with lengths higher than those found in environments of introductions (Zaret, 1980; Winemiller et al., 1997). Sexual maturity can be achieved in different sizes or ages. For the same species, different patterns of growth in different environments may be found (Carmassi et al., 2008).

In natural environments, the peacock bass has a variety of food items, preying on the most abundant species (Winemiller et al., 1997, Williams et al., 1998). In the Volta Grande Reservoir and in the lake in Leme the peacock bass shows, as the main food, fish from their own gender (cannibalism) (Gomiero and Braga, 2004a; Naous, 2008). In populations with cannibalism, the stability is greater and the probability of extinction is lower, the similar plasticity can occur with growth ensuring the full development of these invasive populations. Throughout the life cycle, individuals of an age group are subject to different rates of predation, and according to the increase of size, the natural mortality is reduced, making the number of individuals smaller and more vulnerable to predators (Fonteles-Filho, 1989).

In tropical areas, the growth rates are higher, the fish matures at a younger age and the lifetime is shorter (LoweMcConnell, 1999). The period of food is the main factor limiting the performance of growth in tropical areas, while the temperature is the main factor in temperate waters (Boujard et al., 1991).

Growth rates and mortality of $C$. kelberi in Leme were higher than those of $C$. kelberi and C. piquiti at Volta Grande. In contrast, as might be expected, the asymptotic length and longevity were lower (Sparre et al., 1989; Lizama and Vazzoler, 1993; King, 1996). According to Table 1, the total mortality rate of Cichla monoculus in the Amazon was much higher than those found in Leme and Volta Grande (Ruffino and Isaac, 1995). In natural environments, the peacock bass has several predators and commercial fishing or subsistence is another important factor that contributes to mortality in these populations. Natural mortality among young fish (larvae and juveniles up to 1 year) of peacock bass in Venezuela is very high and, under natural conditions, the recruitment of young adults in the population is very low (Winemiller, 2001). Other features of natural populations of Cichla were high values of asymptotic length, low values of growth and high longevity (Ruffino and Isaac, 1995; Novoa, 1996; Winemiller et al., 1997; Jepsen et al., 1999).

Such differences between the populations of native and introduced of predatory fish seem to be common. The black bass (Micropterus salmoides Lacepède, 1802) coming from North America and introduced into a small reservoir in southern Brazil showed lower values in the max length and of longevity, and higher rates of growth and mortality than native populations (Schulz and Leal, 2005).

The growth of Cichla, in the Amazon, fluctuates seasonally with lower rates in the early dry (less food) (Ruffino and Isaac, 1995). In many species of fish, growth rates vary widely according to environmental conditions, food availability and factors affecting its use, such as temperature and population density (Lowe-McConnell, 1999).

Due to the high population density and lack of resources found in environments of introduction, larger individuals prey on juveniles of their own species. Thus, that pressure to grow quickly increases in smaller and less diverse environments, causing larger rates of mortality and growth, as well as smaller lengths, rates of survival and longevity. Therefore, it can be concluded that the genus Cichla fits well in locations where it is introduced, however, this adaptation shows itself strongly fitted to each particular environment, determining this great plasticity and the capacity to establish itself.

\section{References}

AGOSTINHO, AA. and JÚLIO Jr., HF., 1996. Peixes de outras águas. Ciência Hoje, vol. 21, no. 124, p. 36-44.

BASSON, M., ROSENBERG, AA. and BEDDINGTON, JR., 1988. The accuracy and reliability of two new methods for estimating growth parameters from length-frequency data. Journal du Conseil International Explorer de Mer, vol. 44, p. 277-285.

BEDARF, AT., MCKAYE, KR., VAN DEN BERGHE, E., PEREZ, LJL. and SECOR, D. H., 2001. Initial six-year expansion of an introduced piscivorous fish in a tropical Central American lake. Biological Invasions, vol. 3, p. 391-404.

BOUJARD, T., LECOMTE, F., RENNO, JF., MEUNIER, F. and NEVEU, P., 1991. Growth in four populations of Leporinus friderici (Bloch, 1794) (Anostomidae, Teleostei) in French Guiana. Journal of Fish Biology, vol. 38, no. 3, p. 387-397.

BRAGA, FMS. and GENNARI FILHO, O., 1991. Estudos sobre a fecundidade, desova e mortalidade natural de Moenkhausia intermedia (Characidae, Tetragonopterinae) na represa de Barra Bonita, rio Piracicaba, SP. Naturalia, vol. 16, p. 55-68. 
BRAGA, FMS. and GOMIERO, LM., 1997. Análise da pesca experimental realizada no reservatório de Volta Grande, rio Grande (MG-SP). Boletim do Instituto de Pesca, vol. 24, p. 131-138.

BRAGA, FMS., 1990. Aspectos da reprodução e alimentação de peixes comuns em um trecho do rio Tocantins entre Imperatriz e Estreito, Estados do Maranhão e Tocantins, Brasil. Revista Brasileira de Biologia = Brazilian Journal of Biology, vol. 50, no. 3, p. 547-558.

-, 1999. Idade, crescimento e taxas de mortalidade de Astyanax bimaculatus (Characidae, Tetragonopterinae) na represa de Barra Bonita, rio Piracicaba (SP). Naturalia, vol. 24, p. 239-250.

CARMASSI, AL., SILVA, AT., RONDINELI, GR. and BRAGA, FMS., 2008. Biologia populacional de Cyphocarax modestus (Osteichthyes, Curimatidae) no córrego Ribeirão Claro, município de Rio Claro (SP). Biota Neotropica, vol. 8, no. 1, p. 110-114.

CASTRO, PMG., CERGOLE, MC., CARNEIRO, MH., MUCINHATO, CMD. and SERVO, GJM., 2002. Crescimento, mortalidade e taxa de explotação do goete, Cynoscion jamaicensis (Perciformes: Sciaenidae), na região sudeste/sul do Brasil. Boletim do Instituto de Pesca, vol. 28, no. 2, p. 141-153.

ELVIRA, B. and ALMODÓVAR, A., 2001. Freshwater fish introductions in Spain: facts and figures at the beginning of the 21st century. Journal of Fish Biology, vol. 59, no. sA, p. 323-331.

ESPINOLA, LA., 2005. Tática reprodutiva e estrutura da população de Cichla monoculus Spix \& Agassiz, 1831 (Perciformes, Cichlidae) em ambientes com diferentes regimes hidrológicos. Maringá: Universidade Estadual de Maringá, 23 p. [Dissertação de Mestrado].

FONTELES-FILHO, AA., 1989. Recursos pesqueiros. Biologia e dinâmica populacional. Fortaleza: Editora da Impressa Oficial do Ceará.

GAYANILO Jr., FC. and PAULY, D., 1997. FAO-ICLARM Stock Assessment Tools (FISAT) Reference Manual. FAO Computerized Information Series (Fisheries), vol. 8, p. 1-262.

GAYANILO Jr., FC., SPARRE, P. and PAULY, D., 1996. The FAOICLARM Stock Assessment Tools (FISAT) User's guide. FAO Computerized Information Series (Fisheries), vol. 6, p. 1-186.

GOMIERO, LM. and BRAGA, FMS., 2003a. Pesca experimental do tucunaré, gênero Cichla (Osteichthyes, Cichlidae), no reservatório da UHE de Volta Grande, rio Grande $\left(48^{\circ} 25^{\prime}-47^{\circ} 35^{\prime} \mathrm{W}, 19^{\circ}\right.$ $57^{\prime}-20^{\circ} 10^{\prime}$ S). Boletim do Instituto de Pesca, vol. 29, no. 1, p. $29-37$

-, 2003b. Relação peso-comprimento e fator de condição para Cichla ocellaris e Cichla monolucus (Perciformes, Cichlidae) no reservatório de Volta Grande, Rio Grande - MG/SP. Acta Scientiarum Biological Sciences, vol. 25, no. 1, p. 79-86.

-., 2004a. Cannibalism as the main feeding behaviour of tucunares introduced in Southeast Brazil. Revista Brasileira de Biologia = Brazilian Journal of Biology, vol. 64, no. 3b, p. 625-632.

-, 2004b. Feeding of introduced species of Cichla (Perciformes, Cichlidae) in Volta Grande Reservoir, river Grande (MG/SP). Revista Brasileira de Biologia = Brazilian Journal of Biology, vol. 64, no. 4, p. 787-795.

,$- 2004 \mathrm{c}$. Reproduction of species of the genus Cichla in a Reservoir in Southeastern Brazil. Revista Brasileira de Biologia $=$ Brazilian Journal of Biology, vol. 64, no. 3b, p. 613-624.
GOMIERO, LM., CARMASSI, AL. and BRAGA, FMS., 2007. Crescimento e mortalidade de Brycon opalinus (Characiformes, Characidae) no Parque Estadual da Serra do Mar, Mata Atlântica, Estado de São Paulo. Biota Neotropica, vol. 7, no. 1, p. 22-26.

GOMIERO, LM., VILLARES Jr, GA. and NAOUS, F., 2008. Relação peso-comprimento e fator de condição de Cichla kelberi (Perciformes, Cichlidae) introduzidos em um lago artificial no Sudeste Brasileiro. Acta Scientiarum Biological Sciences, vol. 30, no. 2, p. 173-178.

-, 2009. Reproduction of Cichla kelberi Kullander and Ferreira, 2006 introduced into an artificial lake in southeastern Brazil. Revista Brasileira de Biologia = Brazilian Journal of Biology, vol. 69 , no. 1 , p. 175-183.

HOEINGHAUS, DJ., LAYMAN, CA., ARRINGTON, DA. and WINEMILLER, KO., 2003. Movement of Cichla species (Cichlidae) in a Venezuelan floodplain river. Neotropical Ichthyology, vol. 1, no. 2, p. 121-126.

JEPSEN, DB., WINEMILLER, KO., TAPHORN, DC. and OLARTE, DR., 1999. Age structure and growth of peacock cichlids from rivers and reservoirs of Venezuela. Journal of Fish Biology, vol. 55, no. 2, p. 433-450.

KING, M., 1996. Fisheries biology, assessment and management. Oxford: Black Science.

LIZAMA, MAP. and AMBRÓSIO, AM., 2003. Crescimento, recrutamento e mortalidade do pequi Moenkhausia intermedia (Osteichthyes, Characidae) na planície de inundação do alto rio Paraná, Brasil. Acta Scientiarum Biological Sciences, vol. 25, no. 2, p. 329-333.

LIZAMA, MAP. and VAZZOLER, AEAM., 1993. Crescimento em peixes do Brasil: uma síntese comentada. Revista UNIMAR, vol. 15, p. 141-173.

LOWE-MCCONNELL, RH., 1999. Estudos ecológicos de comunidades de peixes tropicais. São Paulo: Editora da Universidade de São Paulo, 535 p

MACHADO-ALLISON, A., 1990. Ecologia de los peces de las areas inundables de los llanos de Venezuela. Interciencia, vol. 15, no. 6, p. 411-423.

MATEUS, LAF. and PETRERE Jr., M., 2004. Age, growth and yeld per recruit analysis of the pintado Pseudoplatystoma corruscans (Agassiz, 1829) in the Cuiabá river basin, pantanal matogrossense, Brazil. Revista Brasileira de Biologia $=$ Brazilian Journal of Biology, vol. 64, no. 2, p. 257-264.

NAOUS, F., 2008. Dieta do tucunaré amarelo, Cichla kelberi (Kullander \& Ferreira, 2006) (Osteichthyes, Cichlidae), em um lago artificial de pequeno porte em Leme, SP. Universidade Estadual Paulista, 37 p. [Monograph graduation].

NIKOLSKII, GV., 1963. The ecology of fishes. London: Academic Press, 352 p.

-, 1969. Theory of fish populations dynamics. Edinburgh: Oliver \& Boyd, 323 p.

NOVOA, DFR., 1996. Aspectos generales sobre la biologia, pesqueria, manejo y cultivo del pavón (Cichla orinocensis y Cichla temensis) en el lago de Guri y otras áreas de la region Guayana. Natura Caracas, vol. 96, p. 34-39.

PAULY, D. and DAVID, N., 1981. ELEFAN I, a BASIC program for the objective extraction of growth parameters from lengthfrequency data. Meeresforschung, vol. 28, no. 4, p. 205-211. 
PAULY, D. and GASCHUTZ, G., 1979. A simple method for fitting oscillating length growth data, with a program for pocket calculator. International Council for the Exploration of the Sea, Council Meeting 1979/G. Demersal Fish Committe.

PAULY, D., 1979. Theory and management of tropical multispecies stocks - A review, with emphasis on the southeart Asia demersal fisheries. ICLARM Studies \& Reviews, vol. 1, p. 1-35.

-, 1980. On the interrelationships between natural mortality, growth parameters, and environmental temperature in 175 fish stocks. International Council for the Exploration of the Sea, vol. 39, no. 2, p. 175-192.

,- 1983 . Some simple methods for the assessment of tropical fish stocks. FAO Fisheries Technical Paper, vol. 234, p. 1-52.

-, 1998. Tropical fishes: patterns and propensities. Journal of Fish Biology, vol. 53, no. sA, p. 1-17.

RESENDE, EK., MARQUES, DKS. and FERREIRA, LKSG., 2008. A successful case of biological invasion: the fish Cichla piquiti, an Amazonian species introduced into Pantanal, Brazil. Revista Brasileira de Biologia = Brazilian Journal of Biology, vol. 68 , no. 4 , p. 799-805.

RICKER, WE., 1975. Computation and interpretation of biological statistics of fish populations. Bulletin Fisheries Research Board of Canada, vol. 191, p. 1-382.

RUFFINO, ML. and ISAAC, VJ., 1995. Life cycle and biological parameters of several brazilian amazon fish species. NAGA, The ICLARM Quarterly, vol. 18, no. 4, p. 41-45.

SCHULZ, UH. and LEAL, ME., 2005. Growth and mortality of Black Bass, Micropterus salmoides (Pisces, Centrachidae; Lacepède, 1802) in a reservoir in southern Brazil. Revista Brasileira de Biologia = Brazilian Journal of Biology, vol. 65, no. 2, p. 363-369.

SIMBERLOFF, D., 2003. Confronting introduced species: a form of xenophobia? Biological Invasions, vol. 5, p. 179-192.
SOUZA, JE., FRAGOSO-MOURA, EN., FENERICH-VERANI, N., ROCHA, O. and VERANI, JR., 2008. Population structure and reproductive biology of Cichla kelberi (Perciformes, Cichlidae) in Lobo Reservoir, Brazil. Neotropical Ichthyology, vol. 6, no. 2, p. 201-210.

SPARRE, P. and VENEMA, SC., 1992. Introduction to tropical fish stock assessment. Part 1. Manual. FAO Fisheries Technical Paper, vol. 1, p. 1-376.

SPARRE, RR., URSIN, E. and VENEMA, SC., 1989. Introduction to tropical fish stock assessment - Parte 1: Manual. Rome: FAO.

TAPHORN, DCB. and BARBARINO-DUQUE, A., 1996. Evaluación de la situación actual de los pavones (Cichla spp.), en el Parque Nacional Capanaro-Cinaruco, Estado Apure, Venezuela. Natura Caracas, vol. 96, p. 10-25.

WERNER, EE. and GILLIAM, JF., 1984. The ontogenetic niche and species interactions in size-structured populations. Annual Review of Ecology and Systematics, vol. 15, p. 393-425.

WILLIAMS, JD., WINEMILLER, KO., TAPHORN, DC. and BALBAS, L., 1998. Ecology and status of piscivores in Guri, an oligotrophic tropical reservoir. North American Journal of Fisheries Management, vol. 18, no. 2, p. 274-285.

WINEMILLER, KO., 2001. Ecology of peacock cichlids (Cichla spp.) in Venezuela. Journal of Aquariculture and Aquatic Sciences, vol. 9, p. 93-112

WINEMILLER, KO., TAPHORN, DC. and BARBARINO-DUQUE, A., 1997. Ecology of Cichla (Cichlidae) in two blackwater rivers of southern Venezuela. Copeia, vol. 1997, no. 4, p. 690-696.

WOOTTON, RJ., 1992. Fish Ecology. New York: Ed. Chapman \& Hall, 212 p.

ZARET, TM. and PAINE, RT., 1973. Species introduction in a tropical lake. Science, vol. 182, no. 2, p. 449-455.

ZARET, TM., 1980. Life history and growth relationships of Cichla ocellaris, a predatory South American cichlid. Biotropica, vol. 12 , no. 2, p.144-157. 
